University of Warwick institutional repository: http://go.warwick.ac.uk/wrap This paper is made available online in accordance with publisher policies. Please scroll down to view the document itself. Please refer to the repository record for this item and our policy information available from the repository home page for further information.

To see the final version of this paper please visit the publisher's website. access to the published version may require a subscription.

Author(s): Mark Harrison

Article Title: Primary Accumulation in the Soviet Transition

Year of publication: 1985

Link to published version:http://dx.doi.org/ 10.1080/00220388508421970

Publisher statement: None 


\title{
Primary Accumulation in the Soviet Transition*
}

\author{
Mark Harrison**
}

\begin{abstract}
The Soviet background to the idea of primary socialist accumulation is presented. The mobilisations of labour power and of products into public sector investment from outside are shown to have been the two original forms of the concept. In Soviet primary accumulation the mobilisation of labour power was apparently more decisive than the mobilisation of products. The primary accumulation process had both intended and unintended results. Intended results included bringing most of the economy into the public sector, and industrialisation of the economy as a whole. Unintended results included substantial economic losses, and the proliferation of coercive institutions damaging to attainment of the ultimate goal -the building of a communist society.
\end{abstract}

* This paper appeared in the Journal of Development Studies 22:1 (1985), pp. 81-103.

** Mail: Department of Economics, University of Warwick, Coventry CV4 7AL, England. Email: mark.harrison@warwick.ac.uk. I am grateful to the editor, the referees and Dr R. A. Lewis of the Department of Economic History, University of Exeter for helpful comments on an earlier draft 


\section{Primary Accumulation in the Soviet Transition}

"The more backward economically ... a particular country is which has gone over to the socialist organisation of production, ... by so much more, in proportion, will socialist accumulation be obliged to rely on alienating part of the surplus product of presocialist forms of economy and ... the less will it be nourished by the surplus product of the workers in socialist industry" (E. A. Preobrazhensky).

\section{Introduction}

What do we mean by primary accumulation in societies attempting the reorganisation of economic life on socialist lines? Since the term "primary socialist accumulation" was originated in the Soviet Union, and Soviet experience provides the first case of such an attempt, our answer to this question is naturally coloured by our opinions about Soviet history, especially those received from the figures which have populated it. These opinions cannot be evaluated, and our question cannot be answered, without first undertaking a review of the historical background against which the concept of primary socialist accumulation first arose.

\section{Background}

The Soviet Union of the 1920 s possessed a new kind of "mixed" economy. The mixture was a direct result of the way in which the Soviet regime had appropriated its economic legacy bequeathed from the prerevolutionary era. Before 1917 Russia had been the least industrialised of the great powers or the most industrially developed of the world's primary producing and exporting nations. Her economy had been organised by means of a combination of feudal, capitalist and statecapitalist forms, one result of which was a pervasive dualism. In industry and trade a limited number of giant cartels (among them, the first modern transnational companies) operated alongside hundreds of thousands of artisan producers and market traders. In agriculture, which accounted for over half of 1913 national income and at least 70 per cent of employment [Gregory, 1972:425; 1982:132-5], big latifundia ran side by side with 16 million peasant farms. Spontaneous forces for economic development flowed in a confused stream, sometimes with and sometimes against the currents deliberately induced by government and monopoly capital [e.g. Crisp, 1976: 52-4].

The transformations enacted as a result of Russia's revolutions and civil war brought radical change to this economic structure. Large-scale industry and finance entered the public sector in 1917-18. Small industries, closed or nationalised in 1918-20, were revived and returned to the private sector after the New Economic Policy (NEP) was initiated in 1921. The state became a monopoly supplier of industrial capital goods, of formal credit and of imports; a dominant agent in the 
supply of manufactured goods to the retail market, and the most important purchaser of grain from the agricultural producer. In agriculture itself the old dualistic structure was swept away by incorporation of latifundia into the economy of the small producers; public enterprise was introduced but remained vestigial, more than 98 per cent of sown area being maintained on small peasant farms [Nove, 1982:102-6]. Pronounced levelling tendencies within the peasantry had the further result that small capitalism was greatly weakened; in the mid-1920s, of 20 million peasant farms, only three-quarters of a million could be thought of as reliant on hired labour [Danilov, 1977: 57].

In the Soviet economy as a whole the public sector, even including cooperative enterprises, was therefore comparatively small. It accounted for all banking (that is, formal credit institutions, but not petty rural credit) and foreign trade, three-quarters of industrial output (but a substantially smaller fraction of industrial employment), most of wholesale and from half to two-thirds of retail trade, but it played practically no part in agricultural production. Moreover, agriculture remained the dominant sector of the economy in terms of both national income and employment shares.

Should we identify the quantitative role of an economy's public sector with the degree of its socialisation? The existence of a public sector may well be a necessary condition for establishing social ownership and control of an economy, but it is clearly not sufficient. Nor is it necessarily the case that an increase in the degree of social control requires an increase in the share of the public sector under all circumstances. ${ }^{1}$ If the public sector in the Soviet economy of the 1920 s was limited in size, was the degree of socialisation correspondingly low?

From the point of view of the managerial relations of production, work in the public sector was still organised on hierarchical, authoritarian lines. The voices of workers' direct control and elective self-management, once prominent both in the factory and on the left of the Soviet regime, had been stilled during the struggle for unanimity around the Bolshevik leadership which had attended the revolutionary process and civil war. It is true that both hierarchy and authority were far less pronounced than in the pre-revolutionary workplace, and workers' representatives now occupied an indispensable place in the management structure. Soviet trade unions, however, were in the process of assuming a more centralised and disciplined form.

In the private sector (mainly in agriculture and trade), the revolution had injected both communal and co-operative forms with new life. The whip hand of the bailiff had been struck aside and the fist of the kulak (the small capitalist farmer or moneylender) relaxed. But the extent to which such new freedoms could be made the preconditions for new kinds of real social ownership and control was

${ }^{1}$ The distinction between public and social ownership owes much to the work of Polish economists dating back to the 1950 os and 1960s. See, for example, Brus [1975: 18-24]. 
very much an open question given the small-scale, in part selfsufficient, character of production.

From the point of view of establishing social control over the macroeconomic system, the regime possessed - in principle - a wide array of policy instruments and direct controls. These ranged from the control of credit, taxation and foreign trade to the direct regulation of public sector output, prices and employment. Translating these apparent powers into effective authority, capable of realising objectives laid down in advance while remaining sensitive to the new difficulties and demands which would emerge only in the course of economic development, was another matter. The regime was characterised by self-confessed "bureaucratic deformations" - maladministration, illiteracy, corruption, authoritarianism. Whether or not the regime itself was subject to control by society is a related question (involving the character of Soviet society as much as that of the regime) which can scarcely be resolved here. But it can be said that here was a regime in which controls and prohibitions wielded over the heads of the population were offset to some degree by many innovative participatory forms and channels for popular expression - at this stage, even of some dissent - so that the answer is unlikely to be categorical; even a qualified "yes" or "no" might not suffice.

To what extent did the performance of this economic system match the needs of Soviet society? In the 1920s the Soviet economy expanded rapidly and evolved dynamically. This growth has been evaluated in relation to the level and rate of economic development achieved before 1914. Between 1914 and 1921 the economy suffered a terrible blow. Agricultural production fell by a third and industry was virtually closed down. By 1920 trade had ceased or been driven underground, being replaced by black markets, barter, administrative rationing and requisition. Empty factories and uncultivated land meant that, by the post-war period, in spite of the premature death or disablement of millions of citizens, the Soviet economy possessed substantial reserves of unutilised capacity. The pre-war level of output achieved within post-war frontiers is often taken, therefore, as a benchmark for the restoration of Soviet economic activity. In the view of the Birmingham Soviet Industrialisation Project researchers, by 1926/7 Soviet industrial production was already from two per cent to six per cent higher than in 1913 [ Wheatcroft, Davies and Cooper, 1982: 3]. In agriculture grain harvests lagged behind - only in the best year, 1926, was the 1909-13 average matched, and this was still 15 per cent below the pre-war best of 1913. But, even in 1926, grains accounted for less than one-quarter (by value) of gross agricultural production. Moreover, the grain deficiency was more than offset by a shift to mixed farming with more intensive arable crops and livestock. By 1926, agricultural output as a whole had just matched or exceeded (by one-half to two per cent) the 
1913 benchmark [Wheatcroft, Davies and Cooper, 1982: 3-4;

Wheatcroft, 1984: 45-7]. ${ }^{2}$

In terms of its rate of development the NEP economy also compared favourably with historical precedents. After post-war recovery agriculture continued expansion only at a sluggish rate, ceasing after 1928 , but within the aggregate the pattern continued to improve. The traditional grain monoculture was giving way to improved livestock and intensive arable crops. Livestock herds were growing at three per cent to four per cent per annum compared to the 1890-1913 average of less than two per cent [Danilov, 1977: 277-301]. Meanwhile large-scale industrial production was expanding at a rate substantially higher than that established by the pre-war trend, and was even accelerating as it passed the level of the 1913 benchmark, reaching more than 20 per cent over the previous year in 1927/8 and 1928/9. However, small industries stagnated [Carr and Davies, 1974: 1004].

Assessment of overall growth rates is rendered complex by the need to allow for the element of recommissioning existing capacity which had been temporarily closed down during the war years. This element was still present in the late 1920s, even after pre-war output levels had been surpassed, and helps to explain the rapidity of industrial growth. However, the restoration of existing capacity was certainly not the only explanation for the dynamism of the NEP economy. By 1926/7 net industrial investment was at least 20 per cent higher than in 1913, and large-scale industrial fixed capacity was growing at more than 13 per cent per annum. In agriculture investment in livestock in 1926/7 was no less than three-and-a-half times the 1913 level. But these gains were largely at the expense of investment in urban housing and farm buildings, so that net investment in the economy as a whole had not quite recovered to the 1913 level [Wheatcroft, Davies and Cooper, 1982: 5-6]. All the same the mobilisation of existing capacities, and of investment resources for the creation of new capacities within NEP was sufficiently impressive that the "replacement crisis" feared by many, in which the productive assets acquired from the pre-revolutionary era would wear out and leave behind them a declining economy, did not materialise.

To what extent did this pattern of accumulation meet social and governmental aspirations? Under NEP the peasantry enjoyed major benefits. Following the expulsion of the landlords and breakdown of the rural state apparatus they commanded a much higher proportion of the land and other agricultural assets than before the revolution and, with the sharp decline in their compulsory obligations, they retained a bigger share of what they produced [Barsov, 1969: 70-71]?3 Out of

2 This assessment is more optimistic than that of Gregory [1982: Chapter 5 ] concerning which the Birmingham authors express reservations.

3 The most famous comment on this phenomenon is found in the use made by Stalin of statistics on grain production and marketings in $1926 / 7$, produced by the economist V. S. Nemchinov, in a speech in 
increased retentions they were able both to invest more and to eat better. Farming became a healthier profession both from a production and from a consumption point of view. The urban strata, especially the workers, were placed in a more ambiguous position, since food shortages constantly threatened living standards, job creation and other gains of the October 1917 revolution. By the late 1920 s ambitious investment programmes for public sector industries were tending to outrun the supply of investment goods available, and to stimulate consumer demand faster than new capacity could be created. Resulting shortages of manufactured consumer goods were also damaging to urban food supplies, since food producers preferred to retain marketable output rather than exchange it for cash which could not be spent (for accounts of the "goods famine" see Davies [1980: 39] and Nove [1982:139-40]). Moreover, public sector investment plans, although ambitious in relation to the economy's ability to supply them, were too small in relation to the regime's perception of investment needs. In the outturn, when scarce investment goods were rationed among competing public sector claimants according to a crude priority system, major sectors such as education, housing, transport and the defence industries were starved of new assets [ Wheatcroft, Davies and Cooper, 1982: 7]. Thus although the NEP economy expanded rapidly and evolved dynamically, its evolution was neither harmonious nor unforced.

The fullest implications of these dilemmas are revealed when we place the NEP economy in its international setting. Historically Russia had depended on the West for the import of both savings and industrial technology. The Soviet regime was learning to substitute domestic for foreign savings, but at the cost of growing internal disequilibrium. It was proving just as difficult to create domestic sources of machinery for efficient, resource-saving innovation. At the same time the resource cost of imported machinery was growing, because there was less grain available for export, while in the world market the terms of trade were shifting decisively against primary producers. The range of external military threats was widening as the gains from trade diminished.

Could NEP have been maintained in spite of these difficulties? Elsewhere I have written that the NEP economy might have yielded continued economic expansion with less industrial growth, more agricultural revolution and more attention to living standards than were obtained under Stalinist industrialisation after 1929. But in following this alternative just as many problems would have arisen as were actually faced and resolved, suppressed or deferred under Stalin. For some this means that effectively there was no alternative to Stalinist industrialisation [e.g. Vyas, 1978:160-74; 1985 (forthcoming)]. Certainly, not all the preconditions were already in place for building a viable, defensible socialist economy along NEP lines. My conclusion is that the continuation of NEP was a real option, but we cannot say with hindsight that it would have led to a more humane or prosperous world [Harrison, 1981-82: 403-4; 1984: 73-4].

April 1928, to argue the case for collectivisation; see Stalin [1940: 208 ("On the Grain Front")]. 
The actual outcome was that NEP was abandoned in 1929 in order to safeguard the ambitious public sector investment programme. Forced rapid industrialisation had already begun, and the decisive phase of farm collectivisation followed rapidly. This process has sometimes been referred to as one of "primary socialist accumulation." What did this mean in theory, and does the theory match what happened in history? These are questions to which we may now turn.

\section{Concepts}

Originally, "primary socialist accumulation" formed part of the theoretical system of left-wing Bolshevism. The term was coined by V. M. Smirnov in 1920, and was immediately taken up by N. I. Bukharin [1967:93 ("Ekonomika perekhodnogo perioda")]. However, its most famous exponent in the years 1924-26 became the economist and spokesman for the Trotskyist opposition, E. A. Preobrazhensky. 4 (Meanwhile, Bukharin had changed his views and had become a trenchant critic of the left.) Although they differed in important respects from the start, these writers gave to the term "primary socialist accumulation" a clearly discernible common meaning. It meant the transfer of resources from pre-socialist forms of production into the socialist sector of the economy. The resources transferred would finance accumulation within socialist relations of production. Socialist accumulation was held to be a special problem in a less developed economy, because initial acts of nationalisation of a few large-scale enterprises would result in only a small public-sector enclave within the economy as a whole; the latter would remain dominated by small capitalists and peasant producers and traders. The socialist sector would be unable to develop autonomously either in national terms (because of the need to attract foodstuffs, raw materials and labour power from the private sector), or in world terms (because of the competitive dominance of more industrially developed capitalist nations). Hence the need for a primary phase of accumulation in which the socialist sector would expand by means of a net transfer of resources from the private sector and, to this extent, at its expense.

The concept of primary socialist accumulation marked an important step forward in Marxist political economy. This was because it tended to challenge the idea that socialisation of the economy requires nothing more than a series of acts of expropriation or nationalisation. Instead it suggested that the transition to socialism only begins with the creation of a public sector; this is followed by a possibly lengthy evolutionary process within which the transition to socialism must be managed by means of policy choices, policy instruments and management institutions. Here was a major discovery.

At the same time, with the help of hindsight, we can isolate three major defects in this original concept. First was an unquestioned

4 Preobrazhensky's law of primary socialist accumulation, first formulated in 1924, can be found in English translation in Preobrazhensky [1965: Chapter 2 ("The Law of Primitive Socialist Accumulation”)]. 
identification of socialist relations of production with the public sector, and of state ownership with social ownership and control. However, even if the creation of a public sector is the start of the socialisation process, then the process of socialisation which follows cannot be limited only to the quantitative expansion of the public sector. Also involved is the qualitative transformation of managerial relations of production within the public sector. If public sector industries reproduce capitalist hierarchy and managerial authority, then the socialisation process has not been advanced thereby. What is more, socialisation processes need not be confined to the public sector, since worker initiatives and co-operative or community developments in the private sector can also challenge and help to transform pre-socialist relations of production. However, the concept of "primary socialist accumulation" in its original version paid no attention to these issues and focused single-mindedly upon accumulation in the public sector, regardless of the managerial relations of production through which it would be organised. 5

Second, if Bukharin (in 1920) or Preobrazhensky (in 1924-26) had anything to say about the production relations appropriate to a socialist transition, it was to define them as centralised and coercive. For Bukharin [1967: 93-5] this was the consequence of a direct analogy with primary capitalist accumulation - under capitalism primary accumulation had been bloody and forced; so too would it be under socialism, although under socialism the sacrifices and disciplines ought to be collective and self-imposed. For Preobrazhensky [1965: 120-31], on the other hand, the analogy was indirect - primary capitalist accumulation had not just been brutal and bloody but had also depended to some degree upon the competitive advantage of capitalist enterprise; however, this advantage would be denied to public enterprise in a less developed country, so that primary socialist accumulation could only be organised on the basis of economic and political monopoly. Thus for each writer the result was the same, although the reasoning was different -a deterministic model of socialist production relations in which the general will of the working class would be realised exclusively through centralised authority and administrative controls. Within this setting, the socialisation process was reduced to pumping resources from the private into the public sector, while the socialist production relations within the public sector where these resources would be set to work were seen as predetermined and static.

5 Filtzer [1978: 77-8] has argued that Preobrazhensky recognised this aspect of primary accumulation in terms of the need to overcome the division of labour in society (including managerial hierarchy) through "proletarian democracy" and the appropriation of knowledge by the working class; Filtzer comments, however, that this aspect of Preobrazhensky's theory "fought for a platform which effectively 'presupposed itself', in that its prior implementation was an actual condition for its adoption." 
The third major defect was that each writer saw primary socialist accumulation as proceeding along a one-dimensional course, and in each case the chosen dimension had been generalised from a highly specific historical conjuncture. For Bukharin [1967: 94; see also Szamuely, 1974: 41] in 1920, surrounded by the wreckage of war, the key dimension seemed to be the allocation of labour power. For him, primary socialist accumulation meant the mobilisation and militarisation of labour from beyond the ranks of the existing working class. Conscription of the peasantry into public works would provide the necessities for industrial reconstruction on socialist lines. Although popular for a short time (at least among Bolsheviks) this idea was shelved in 1921 with the relaxation of wartime controls and initiation of NEP. When Preobrazhensky [1965:91-112] revived "primary socialist accumulation" in the NEP context, the priorities had changed. Now the key dimension appeared to be the mobilisation of the agricultural surplus product and its transfer to public sector industries by means of direct and indirect taxation of peasant producers. In each case the result was too much stress on a single aspect of the inter-sectoral circulation of resources (whether of labour power or of products), to the detriment of the conceptual inter-relatedness of the economic system as a whole. Rather than adopt one or another of these versions of what primary socialist accumulation really meant, it would be preferable to state that since 1917 Soviet economic development has passed through several different phases and that in each of them primary socialist accumulation took a different form.

The precise origins of "primary socialist accumulation" and what its originators may or may not have intended have recently been discussed at some length. This all-too-absorbing subject is of some importance to us, partly because for many years Western economists based their understanding of the real course of Soviet primary accumulation processes on a simplified rendering of Preobrazhensky's prescriptions. But this basis has been challenged, and major revisions of our understanding of what happened in history have followed [e.g. Millar, 1970 and 1974; Szamuely, 1974; Ellman, 1975; Millar, 1976 and 1978; Ellman, 1978; Vyas, 1978 and 1979; Harrison, 1981-82 and 1984; Vyas, 1985].

At the centre of the simplified version was the peasantry as the principal source of public sector investment funds for Soviet industrialisation after NEP. The means of primary socialist accumulation were supposed to have been agricultural products exchanged by peasants against the industrial outputs of the public sector at unfavourable terms of trade - the famous price "scissors." General secretary I. V. Stalin had adopted (in 1928) the objective of securing a temporary "tribute" from the peasantry to finance rapid industrialisation [e.g. Lewin, 1968:258]. By opening the scissors against the peasant, as Preobrazhensky had recommended, it was held that the Soviet state had squeezed farm incomes and reduced the ability of the village to command the outputs of public sector industries. At the same time the danger that, in response to declining terms of trade, the peasants would cut back sales of foodstuffs or withdraw from the market altogether - which Alexander Erlich [1950: 81] called "the 
Preobrazhensky dilemma" - was averted by the policy of farm collectivisation; this enabled the supply of foodstuffs to be maintained by means of direct pressure. Thus, according to this view, the peasantry was the main contributor to primary accumulation, which took the form of a redistribution of claims on output in favour of public sector investment; the principal methods of primary accumulation were the price "scissors" and farm collectivisation.

In reality Soviet primary accumulation did not follow this pattern. The exchange of commodities between industry and agriculture was not the sole dimension of primary accumulation, and may not have provided a source of primary accumulation funds at all. The price "scissors" proved extremely resistant to manipulation by the public sector, and their real movement did not follow the course recommended by Preobrazhensky. Preobrazhensky's dilemma was probably not binding, nor was it the decisive stimulus to farm collectivisation. His concept of "primary socialist accumulation" was supposed to be the essential precondition for rapid industrialisation based on the public sector but, even without it, rapid industrialisation and public sector expansion proceeded anyway. Essential to Soviet primary accumulation in reality was the fact that managerial relations of production in the public sector, and the economic system as a whole, were both being reorganised - just as much as that resources were being transferred from the private to the public sector. Here there was more at stake than just a choice among different methods all leading to a common objective - the construction of a socialist society. Also involved was a choice among objectives, answering the question: what kind of socialism?

\section{Objectives and Methods}

The Soviet debate over "primary socialist accumulation" may appear to have been a matter of means, not ends - as though all Bolsheviks held a roughly shared conception of their ultimate goal, and the discussion among them was limited to the desirable speed for attaining it and methods for doing so. Doubtless this was how it appeared at the outset to those involved. In retrospect, however, we can see that this distinction between ends and means is too simple. The reality is that ends and means rarely form a simple hierarchy or are easily separable. Means must be designed with the end in view; if the objective is not clearly perceived, then the design of policy will incorporate unforeseen distortions which may limit or even prevent attainment of the given goal. Means which turn out not to lead to the designated objective will have some other outcome instead. When ends and means prove incompatible it may suddenly transpire that the means are more precious than the original end, attainment of which is deferred or abandoned. Of course in many cases there will be several different routes to the same destination and, under these conditions, the choice of route will rest primarily on considerations of speed and economy of effort. But in other circumstances what is apparently a choice of means to an end will turn out to involve the choice of ends as well. Here different means incorporate different objectives and may be taken to 
stand for them; they become just as charged with value (or its opposite) as the goals to which they correspond.

In theory Bolshevism was directed towards a classless society in which the state was to have "withered away," coercion being replaced by voluntary association and co-operative creativity. Yet the circumstances of international and social conflict prompted the Soviet regime, from its first moments, to resolute measures of governmental and social coercion. These measures prompted deep divisions within Bolshevism. What was at issue was the appropriateness of such methods on grounds both of expediency (the regime's survival) and of principle (the regime's permanent objective of a socialist society). The question of expediency was settled in the sense that the regime survived. The question of principle remained unresolved. Was coercion a temporary expedient and the state no more than a necessary evil in the course of struggle for the realisation of human freedom? Or should Bolsheviks attach a positive value to their refinement and extension? And if coercive disciplines and authoritarian centralisation were to become the central themes of Bolshevik practice, what kind of society would result - a society capable of evolving towards the goals originally defined, or some more primitive and limited variant, or even a reversion to something completely antithetical to communist ideals?

It was Bukharin who revealed most clearly the closeness of these issues to the debate over "primary socialist accumulation." He had broken with the left during the period of reassessment immediately following termination of the civil war, and became a leading exponent of the theory and practice of NEP as a possible road to socialism. He criticised both Preobrazhensky's concept of primary socialist accumulation and Stalin's subsequent attempt to secure a temporary "tribute" from the peasantry - the former on the grounds that it would require widespread coercion to prevent peasant withdrawal from the market, losing the goodwill of the peasant masses without whom socialism could not be built in Russia; the latter because Stalin's policies for grain requisitioning initiated in the spring of 1928 amounted to "military-feudal exploitation" of the village [e.g. Cohen, 1975:160-73, 306-7]. In neither case would the outcome be a socialist society. At the time, however, the view that these policies were inappropriate for securing socialist objectives did not prevail.

The Stalinist commitment to coercive methods of authoritarian management arose in the context of the huge gap between aspirations and realities. To the new generation of industrial and economic leaders in the late 1920s backward agrarian Russia appeared to lack all the prerequisites for a socialist society except one - the Soviet political system, which was in their hands. Administrative mobilisation of resources from above became the principal means for realising their grandiose dreams (although, we shall see, it could not be sustained indefinitely or remain their sole reliance). The organisers of Stalin's "great breakthrough" had little interest in the interaction of plan and market, or the role of economic signals within an operationally decentralised public sector. They regarded the market as a seedbed of economic anarchy or, worse, of capitalist renaissance. Their model of a 
socialist economy was primarily one of physical resource allocation by decree [Carr and Davies, 1974: Chapter 32].

The main policy determinants of the pace of industrial development and public sector expansion at the end of NEP were ambitious investment plans adopted at all economic levels (from central government down through regional and local government, the industrial branch and sub-branch down to the enterprise) in the years 1928-30, supplemented by additional directives and decrees. The supplementary measures were of two kinds - upward revisions of plans already adopted, and orders designed to protect existing targets for key sectors (the basic industries, engineering, defence and grain procurement) against the consequences of shortfalls in supplies which arose as ambitious plans were implemented [Zaleski, 1971: Chapters3, 4]. Enforcing these orders took the Soviet economy through a gigantic upsurge. Between 1928 and 1932 under the first Five Year Plan the Soviet national income (at constant 1928 prices) grew by over 60 per cent, virtually all the increase taking the form of industrial output for investment [Barsov, 1969: 90-91].6" Over 11 million jobs were created in the public sector (chiefly in large-scale industry and construction) where employment doubled [Nove, 1982:196]. The weight of the public sector in the economy also increased sharply. By 1932 it had absorbed almost all industrial capacity and, if we include co-operatives, more than three-quarters of agriculture's sown area [Nove, 1982: 174]; state procurements accounted for 96 per cent of farmers' sales [Barsov, 1969: Table 10 (facing p. 112)]. However, the pace of mobilisation of resources into the public sector and into capital construction was so rapid that it could not be sustained. Investment projects overstretched the supply capacity of the industrial system, while production costs rose. Living standards fell in both town and country. In the village collectivisation was inducing a profound crisis of the agricultural system which, after the one good year of 1930, was moving the population rapidly towards a famine condition. After 1930, economic expansion was progressively checked, and extensive reorganisations had to be carried out before rapid mobilisation was resumed in 1934 [e.g. Davies, 1977]. Thereafter the rapidity of economic transformation in 1928-32 was not repeated (nor, at least in peacetime, was the severity of the economic crisis which accompanied it). Rather, as the economy became more industrially developed and more complex, expansion became more sustained while the cycles became somewhat less severe.

\section{Methods and Results}

To what extent did the expansion of public sector investment and employment depend on squeezing peasant farm incomes through manipulation of the price "scissors"? Table 1 shows that by 1925/6 the scissors were as much as 56 per cent less favourable to the peasant than in 1913, but this was not the result of government policy. Higher

${ }^{6}$ Here and below, Soviet national income is measured according to the Material Product System. 
operating costs in Soviet industry meant that the regime was far more preoccupied with trying to force down industrial product prices, in order to squeeze costs and realise reserves of slack capacity, than with letting them rise in order to squeeze the peasant.

Table 1. The "Scissors," 1925/6-1928/9

\begin{tabular}{lrrrr}
$1913=100$ & $1925 / 6$ & $1926 / 7$ & $1927 / 8$ & $1928 / 9$ \\
The "scissors" & 156 & 151 & 137 & 128 \\
\hline
\end{tabular}

Note: The "scissors" are measured by the ratio of an index of retail prices of industrial products to an index of planned delivery prices of agricultural products, based on 1913. Divergences between state planned delivery prices and free market prices for foodstuffs did not become substantial until 1928/9.

Source: Carr and Davies [1974: 1024].

Moreover, the immediately subsequent trend favoured the peasant, not public sector industry - by 1928/9 the adverse shift in the terms of trade compared to 1913 had been reduced from 55 per cent to 28 per cent. Retail prices of industrial goods were reduced in 1927 and held at the lower level, while procurement prices for agricultural goods were being allowed to drift up.

Table 2 shows price indices for 1928-32 in all the main markets in which urban-rural trade took place. Only in 1930 did state and cooperative retail prices for manufactures retailed in the village begin to rise significantly by comparison with state procurement prices for farm products. From this it might be supposed that the conservative public sector pricing policy pursued up until collectivisation stemmed from an appreciation of Preobrazhensky's dilemma - that pushing up industrial prices would spark off a peasant grain strike; once this fear had been lifted by the first wave of collectivisation in 1929-30, industrial prices in the village could be allowed to rise. Both suppositions would be wrong.

Table 2. Price Indices, 1928-32

\begin{tabular}{lrrrr} 
1928 = 100 & 1929 & 1930 & 1931 & 1932 \\
$\begin{array}{l}\text { Producer prices for } \\
\text { agricultural goods: }\end{array}$ & & & & \\
Centrally planned procurements & 111 & 116 & 119 & 109 \\
Decentralised procurements & $\ldots$ & $\ldots$ & $\ldots$ & 354 \\
Free market sales & 233 & 525 & 814 & 3006 \\
Weighted producer prices & 117 & 180 & 199 & 314 \\
Rural purchase prices & & & & \\
for industrial goods: & & & & \\
Investment goods & 100 & 100 & 100 & 100 \\
State and co-operative retail & 101 & 110 & 134 & 292 \\
Free market retail & 111 & 174 & 313 & 674 \\
Weighted user prices & 101 & 110 & 171 & 241 \\
\hline
\end{tabular}

Source: Taken or calculated from A. A. Barsov [1969], Balans stoimostnykh obmenov mezhdu gorodom i derevnei, Moscow: 108, 112$113,115,123$. 
First, it is true that before collectivisation peasants had begun to withhold sales of foodstuffs (especially grains) from state procurement agencies, but the reason was not the adverse terms of trade, which were improving. The reason was that the ambitious public sector investment programme was inflating household purchasing power in both town and country beyond the capacity of consumer industries to satisfy it. Lack of availability of consumer goods forced the seller of foodstuffs to accumulate useless cash, and constituted a disincentive to sell. One solution would have been for the authorities to restrain public sector investment, but this had been ruled out by Stalin. Another option would have been to allow public sector industrial prices to rise. This would have restored macroeconomic equilibrium and food producers' marketing incentives, at the cost of making explicit the reduced living standards required by the public sector investment programme; again this was politically unacceptable.7 While ruling out both of these options, the authorities instead followed a third alternative which made matters still worse. This was to try to reduce peasant incomes and the cost of public sector investment by pushing down the demand price of grains in the grain market, which they largely controlled through procurement agencies, although they could not prevent the demand prices for other kinds of agricultural outputs from rising in the comparatively unregulated markets for livestock and dairy produce, vegetables etc. As a result farmers diverted resources from grain cultivation into these other, more profitable activities; the agricultural system benefited, farm incomes were not reduced, and the supply of grains to the public sector was disproportionately hindered [Davies, 1980: 40].

Second, was collectivisation the decisive factor which allowed the authorities at last to squeeze the peasantry by manipulation of the scissors? It is true that after 1930 the public sector retail prices for industrial goods rose faster than state procurement prices for farm products, but the impact of this development upon the supply of funds for public sector accumulation in industry was more than offset by other changes. One offsetting factor lay in unregulated exchanges within the private sector which persisted (at times illegally) throughout this period. Prices for private sales of foodstuffs and purchases of manufactures both multiplied several times between 1928 and 1932, absolutely and relative to prices obtained in the public sector. But (see Table 2) the free market price of foodstuffs rose by 30 times, compared to only six or seven times for free market manufactures. The persistence of a private sector within agriculture and trade was to have a major effect on the flow of funds between agriculture and industry. For, although virtually all households became worse off, those households which still had access to private supplies of foodstuffs or artisan products could trade on advantageous terms with households

7 If anything, state policy was still to hold industrial prices down, with consequences analysed by Vyas [1979: 26-7]. For more detailed analysis see Harrison [1984: 76-8]. 
reliant on the public sector for their incomes, and best of all was to have food for sale.

The other offset to public sector manipulation of the scissors lay in the fact that, with the creation of a public sector in agriculture, investment in farm capacity now became a charge on public sector resources. At the same time the damage done by collectivisation, in particular widespread losses of draught livestock, had to be made up by the transfer of farm machinery at subsidised state wholesale prices to new public sector agricultural enterprises called "machine and tractor stations"; these transfers were not compensated by immediate reductions in farm household purchasing power.

Why, then, was collectivisation undertaken? Since it was not required to resolve Preobrazhensky's dilemma, and did not increase the resources available to finance industrialisation, it has been argued that the only remaining motives were to back up Stalin's struggle for personal power and to suppress the consequences of leadership blunders such as the attempt to hold down grain prices from 1926 onwards [e.g. Millar, 1976: 53-5]. This view exaggerates what could have been achieved within the NEP framework. The high level of public sector investment being pursued in the late 1920s was increasingly incompatible with NEP, given the right (enshrined in NEP) of the peasant farmer to command resources for agriculture and consumption. To this extent the growing state of shortage and macroeconomic disequilibrium was inevitable [Wheatcroft, Davies and Cooper, 1982:32]. The Soviet regime was in the process of formulating a definite intention to make the transition away from a demandconstrained economic system to a resource-constrained economy characterised by "expansion drive" and "investment hunger" [e.g. Kornai, 1980:191-5], and the market relation with the peasantry would have suffered under any policy design, no matter how finely calculated. At the same time the choice of methods and rate of collectivisation undoubtedly reflected specific features of nascent Stalinism - its impatient desire to get things done, its intolerance of constraints and pragmatic willingness to substitute coercion for consent - with results tragic for agriculture and the rural population. The collectivisation drive was also characterised by highly exaggerated expectations about what would prove technically possible in a large-scale, socialised agriculture given the short time horizon and extremely limited public sector investment resources available for farming, and these expectations would be disappointed in a most brutal clash with reality [Davies, 1980: Chapter 10].

When we take into account the volumes of resources being transferred between the different sectors through different markets, what was the net impact upon Soviet primary accumulation? Research has concentrated on the net transfer between agriculture and industry, rather than between the private and public sectors. The pioneer in this field, the Soviet economist A. A. Barsov [1969: Table 10 (facing p. 112) and p. 118], has calculated that during collectivisation the commodity terms of trade moved in favour of agriculture, although the extent of this movement proved highly unstable in the short term. When the resource transfers themselves are valued in constant 1928 prices, it is 
claimed that agriculture received subsidies from industry throughout the period 1928-32, and that the net subsidy tended to increase while collectivisation proceeded. This result should no longer be considered surprising, given that 17 years have passed since its first publication in a Soviet journal in 1968.

Barsov's findings have been criticised on various grounds. Alec Nove [1976: 58] has called into question whether such flows are in principle measurable, given the turmoil of Soviet economic reality in these years. Another area for criticism has been Barsov's reliance (understandable, however, under the circumstances) on Soviet official statistics [Morrison, 1982: 577-80].

On a more practical level, R. W. Davies and S.G. Wheatcroft have suggested that Barsov neglected the role of rural non-agriculture in claiming agricultural resources and supplying the agricultural population. Empirically, Barsov may have conflated agriculture with the village and the private sector, and public sector urban nonagriculture with non-agriculture as a whole. The importance of this lies in the role played by private sector rural non-agriculture before 1930, and its rapid elimination in the course of farm collectivisation.

Table 3. Agriculture's Sales and Receipts, 1928-32

\begin{tabular}{|c|c|c|c|c|c|}
\hline Billion 1928 roubles & 1928 & 1929 & 1930 & 1931 & 1932 \\
\hline \multicolumn{6}{|c|}{ Agriculture's sales to non-agriculture: } \\
\hline To urban non-agriculture (1) & 3.2 & 3.5 & 4.0 & 4.2 & 3.2 \\
\hline To all non-agriculture (2) & 3.4 & 4.0 & 3.9 & .. & .. \\
\hline Residual attributable to rural & & & & & \\
\hline non-agriculture $(2-1)$ & 0.2 & 0.5 & .. & .. & .. \\
\hline \multicolumn{6}{|c|}{$\begin{array}{l}\text { Agriculture's purchases from non-agriculture: } \\
\text { Investment goods from urban }\end{array}$} \\
\hline $\begin{array}{l}\text { non-agriculture ( } 3 \text { ) } \\
\text { Consumer goods from urban }\end{array}$ & 0.6 & 0.7 & 0.9 & 1.4 & 1.4 \\
\hline non-agriculture (4) & $3 \cdot 4$ & 4.1 & 4.4 & $3 \cdot 7$ & $3 \cdot 3$ \\
\hline $\begin{array}{l}\text { Consumer goods from all non- } \\
\text { agriculture }\end{array}$ & 5.8 & 6.4 & 6.4 & .. & .. \\
\hline $\begin{array}{l}\text { Residual attributable to rural } \\
\text { non-agriculture }(5-4)\end{array}$ & 2.4 & 2.3 & 2.0 & .. & .. \\
\hline \multicolumn{6}{|c|}{ Agriculture's net transfer to non-agriculture: } \\
\hline To urban non-agriculture (6) & -0.8 & -1.3 & -1.3 & -1.0 & -1.6 \\
\hline To all non-agriculture (7) & -3.0 & -3.1 & -3.4 & .. & .. \\
\hline $\begin{array}{l}\text { Residual attributable to rural } \\
\text { non-agriculture }(7-6)\end{array}$ & -2.2 & -1.8 & -2.0 & .. & .. \\
\hline
\end{tabular}

Source: Rows 1, 3, 4 and 6 are from A. A. Barsov [1969], Balans stoimostnykh obmenov mezhdu gorodom i derevnei, Moscow: Table 10 (facing p. 112) and p. 118. Rows 2 and 5 are from R.W. Davies and S.G. Wheatcroft [1983], "Soviet National Income Accounts (Balances) for 1928-30: A Rare Historical Source," Centre for Russian and East European Studies, University of Birmingham: 21-2.

The impact of adopting Davies and Wheatcroft's revisions is shown in Table 3. The role of rural non-agriculture emerges as a set of residuals between two sets of data which may not be fully comparable 
in other ways than those of which we are aware, so it is important not to place too much weight on their accuracy. The table suggests, however, that before collectivisation rural non-agriculture made a substantial net contribution to agriculture - much larger than the urban non-agricultural subsidy - when product flows are measured in 1928 prices. Thus, Barsov greatly understated the flow of resources from industry as a whole to agriculture in 1928-30. The subsequent elimination of rural industries may thus be said to have had two negative consequences - it was a directly retrograde step from the point of view of industrialisation; indirectly it must have increased the dependence of the agricultural population upon the products of public sector urban industries, without increasing the availability of agricultural products. From the point of view of primary socialist accumulation the trade-off between living standards and public sector investment was worsened. But at the same time the elimination of rural industries directly increased the economic weight of the public sector.

Barsov [1969: 130-31; 1974] has also prepared an alternative evaluation of the transfer of resources between agriculture and industry for 1928-32 and 1937-38 in terms of what Michael Ellman [7975] calls "labour adjusted roubles." This involves correction of 1928 prices for the overvaluation of a unit of industrial labour-time in 1928 compared to a unit of agricultural labour-time and for changes in labour productivity after 1928 in both sectors. The prices of 1928 are rejected as a measure of value because they still incorporated the prerevolutionary heritage of exploitation of the agricultural producer by state monopoly capital by means of adverse terms of trade. Barsov estimates the extent of this discrimination as an overvaluation of industrial commodities (and of the labour-time embodied in them) at 1928 prices by a factor of two. In subsequent years this factor would be increased by an increase in labour productivity in agriculture, and reduced by an increase in the same in industry, so Barsov makes appropriate adjustments in the valuation of commodities produced in both sectors in subsequent years (this would be equivalent to correcting the 1928 correction by an index of the double-factoral terms of trade). ${ }^{8}$

8 Barsov [1969:35-50, 125-9] sets out the methodology for correcting 1928 prices. Objections have been raised on a variety of grounds. Millar [1974: 752] objected to the Marxian antecedents of "labour-adjusted" roubles in the labour theory of value, which Millar interpreted as a welfare theory of claims on output. Millar distinguished between the supposedly "straightforward empirical measurement" of intersectoral resource flows, and the measurement of their welfare implications, which requires "choice of a value standard." This distinction does not seem very satisfactory since even conventional neoclassical economics requires an appropriate value standard for measuring inter-sectoral resource flows - in this case, some indicator of long-run marginal costs obtainable under a perfectly competitive equilibrium. Another criticism is raised by Morrison [1982:570-77] - he claims that Barsov's corrections of 1928 prices both distort the Soviet labour productivity record and amount to a 
Table 4 shows the results. When commodity flows are revalued in this way, it emerges that agriculture suffered from unequal exchange throughout the period, but an adverse shift in the terms of trade (the "ratio of non-equivalence") was secured only for 1929-31; by 1932 the labour-adjusted "scissors" were already more favourable than in 1928, and the favourable trend persisted to the late 1930 .

Table 4. Agriculture's Labour-Adjusted Sales and Receipts in 1913, 1928-32 and 1937-38

\begin{tabular}{|c|c|c|c|c|c|}
\hline $\begin{array}{l}\text { Billion labour-adjusted } \\
\text { roubles }\end{array}$ & 1913 & 1928 & $\begin{array}{l}1929-31 \\
\text { average }\end{array}$ & 1932 & $\begin{array}{r}1937-8 \\
\text { average }\end{array}$ \\
\hline Agriculture's sales to & & & & & \\
\hline $\begin{array}{l}\text { non-agriculture (1) } \\
\text { Agriculture's purchases }\end{array}$ & $5 \cdot 54$ & 3.71 & 4.76 & 3.78 & 3.49 \\
\hline $\begin{array}{l}\text { from non-agriculture (2) } \\
\text { Ratio of non-equivalence }\end{array}$ & 1.72 & 1.84 & 2.17 & 1.95 & 2.15 \\
\hline $\begin{array}{l}(1 \div 2) \\
\text { Agriculture's net transfer }\end{array}$ & 3.22 & 2.02 & 2.19 & 1.94 & 1.63 \\
\hline $\begin{array}{l}\text { to non-agriculture }(1-2) \\
(1-2) \text { as share of }\end{array}$ & 3.82 & 1.87 & 2.58 & 1.83 & 1.35 \\
\hline $\begin{array}{l}\text { agricultural output } \\
(1-2) \text { as share of }\end{array}$ & 0.36 & 0.19 & 0.29 & 0.22 & 0.16 \\
\hline industrial investment & & 0.54 & 0.37 & 0.18 & 0.16 \\
\hline
\end{tabular}

Note: Labour-adjusted roubles are defined in the text.

Source: A. A. Barsov [1974], "NEP i vyravnivanie ekonomicheskikh otnoshenii mezhdu gorodom i derevnei," in Novaya ekonomicheskaya politika: voprosy teorii i istorii, Moscow: 96, 99.

Industry did after all receive a net "tribute" from agriculture throughout the inter-war period (this is the result of Barsov's radical downvaluation of industry's sales to agriculture), and the tribute was larger in 1929-31 than in 1928. But the increase in the tribute during collectivisation was only small and temporary. By 1932 it had fallen back to below the 1928 level, and was smaller still in 1937-38 - there

legitimation of wastefully high unit costs in Soviet industry. Again this criticism seems to attach unnecessary moral connotations to a useful heuristic device. Even conventional neoclassical economics recognises the concepts of labour embodied and labour commanded, as definition of the "double-factoral terms of trade" reveals. (The commodity terms of trade are measured by an index of the price of exports divided by an index of the price of imports. The single-factoral terms of trade are measured by the commodity terms of trade multiplied by an index of labour productivity in the export industries of the exporting country, so that a deterioration in the commodity terms of trade may be offset by a reduction in the labour embodied in the exporting country's exports. The double-factoral terms of trade are measured by the single-factoral terms of trade divided by an index of labour productivity in the export industries of trading partners, so that a deterioration in the single factoral terms of trade may be offset by an increase in the labour commanded by exports and embodied in imports.) 
was no recovery after the post-collectivisation famine. As a proportion of industrial accumulation the agricultural tribute declined steadily, from 54 per cent in 1928 to only 18 per cent in 1932 and 16 per cent in 1937-38.

The main emphasis of Barsov's research was placed on resource transfers between industry and agriculture. This is not the same as the focus of primary socialist accumulation which rests on the public sector and its relation with the private sector. However, Barsov's research has been extended to reveal major aspects of primary accumulation. One aspect of this lay in the differential treatment of different sectors within agriculture. In 1928 almost all of agriculture was in small peasant hands. In 1929-30 a large but at first highly unstable socialised sector was formed. By 1932 more than 6o per cent, and by 1937 more than 90 per cent of peasant farms had been collectivised; a substantial nationalised farming industry had also been created. Table 5 shows that in 1930-31 the labour-adjusted (double-factoral) terms of trade were only marginally less favourable to agriculture as a whole than in 1928, and those for the private sector tended to follow those for agriculture as a whole or remain slightly more favourable. Nationalised state farms were far more favourably treated; their terms of trade were twice to four times as advantageous. Collective farms were enormously discriminated against; taking into account the unfavourable terms on which they rented machinery services from the state-owned machine and tractor stations attached to them, their terms of trade with nonagriculture were 14 times less advantageous than those facing state farms in the worst year of 1931, and more than three times as bad as those facing agriculture as a whole. In subsequent years (we have only 1932 and 1938) this pattern of discrimination moderated. But by 1938 , although state farms had lost their advantage, the private sector had improved its position and collective farms were still twice as badly treated as agriculture as a whole. In short, although collectivisation failed to secure more than a small and short-lived increase in the net transfer of resources (measured in labour-adjusted roubles) out of agriculture as a whole, it created new sectors within agriculture and treated them differently. State-owned farms and machine and tractor stations were subsidised at the expense of collective farms; an incidental, and unintended beneficiary was the remaining private sector.

Table 5. The Labour-Adjusted Terms of Trade, 1930-32 and 1938

\begin{tabular}{lrrrr} 
Ratios of nonequivalence & 1930 & 1931 & 1932 & 1938 \\
State farms & 0.82 & 0.55 & 0.51 & 1.92 \\
Collective farms (including machine & & & & \\
and tractor stations) & 4.22 & 4.46 & 2.82 & 1.37 \\
Collective farms alone & 4.75 & 7.75 & 4.64 & 3.17 \\
Private farms & 1.90 & 2.11 & 1.91 & 1.23 \\
All agriculture & 2.04 & 2.31 & 1.94 & 1.64 \\
\hline
\end{tabular}

Note: The ratio of non-equivalence is defined as sales divided by purchases when both are measured in labour-adjusted roubles.

Source: Barsov [1974: 101]. 
Ellman [1975:856] has also extended Barsov's research to examine changes in relations of production within industry, but covering only the years 1928-32. He starts from the proposition that if the net transfer from agriculture to industry fell over the period of the first Five Year Plan, then the increase in industrial investment over the period must have been financed in some other way. He finds its source in the increase in the industrial workforce, coupled with the decline in the real wage cost of output (the latter mainly accounted for by the decline in the real wage). In labour-adjusted value terms it transpires that 30 per cent of the increase in industrial accumulation resulted from the increase in absolute surplus value resulting from increased employment; the increase in relative surplus value resulting from the lower wage cost of output was sufficient to make good both the remaining 70 per cent of the increase in industrial accumulation, and a further 31 per cent shortfall resulting from the decline in the agricultural surplus. The increase in employment was made possible by the administrative mobilisation of resources into public sector capital construction, the imposition of an obligation to work upon the adult able-bodied population of the towns, and the flood of former peasants who left the village to seek work for a wage income. 9 The lower wage cost of output was made possible by a reduction in the real wage paid to both existing and newly employed workers, enforced through inflation, queues, ration cards and the differentiation of rewards for more skilled and responsible grades. All this took place in the context of restructuring of public sector managerial relations of production on the basis of more hierarchical, centralised authority.

Associated with the resource flows and reorganisation of the period were large-scale social mobility and migration. Between 1928 and 1940 state employment almost tripled, with the creation of 20 million new jobs. Until some point in the late 1930s, most new recruits to public sector industry were of peasant origin; of the rural recruits, most were young and without previous experience of non-agricultural wage employment. Other recruits to urban non-agriculture were predominantly women, who increasingly added jobs in the public sector to housework and childcare responsibilities; and school-leavers, who contributed to the natural increase in the workforce.

9 Ellman [1975:857] has argued that, although there was no increase in the net agricultural surplus, the mobilisation both of wage goods marketed by agriculture and of peasant labour was still made possible by farm collectivisation. To this extent collectivisation might still be seen not only as an act of primary accumulation in itself, but also as a necessary condition for the further process of primary accumulation in industry. However Millar [1984] has argued that collectivisation itself was not a necessary condition for the mobilisation of basic wage goods or of labour into industry; once collectivisation had done the damage, the procurements system for basic wage goods (and presumably, too, the system of controls over rural labour mobility and recruitment) merely limited the adverse results. 
The mobilisation of rural labour for public sector capital construction was an exceptionally bewildering affair for those participating in it. Permanent migration from country to town could hold many advantages for the migrant. In general urban living standards were higher than in the countryside, not least because supplies were more assured in times of shortage. Thus, even when living standards were collapsing everywhere, as in the early 1930s, the rural-urban migrant could still benefit. Opportunities for advancement and promotion were also far more numerous in the urban setting, and the hardworking, politically conscious would-be official would almost inevitably leave the village at some point. However, movement to the towns was also fraught with obstacles. Employment as a gang labourer on a building site in a new town which might still be no more than mud and fields was likely to carry more privations than privileges. Opportunities for individual advancement might still be beyond reach. The regime had a multiplying need for cadres and officials, but there was a need for scapegoats too. At lower levels the chance of promotion exceeded the likelihood of personal disaster by some margin, but with rapid advancement up the public sector administrative hierarchy the margin disappeared or at times became negative.

Many were mobilised involuntarily, and entered the field of public sector capital construction as forced labour. Again, the peasantry provided the first echelon for the large-scale application of forced labour - those interned in the course of collectivisation and the agricultural campaigns of the first Five Year Plan. Unfortunately this is a subject where quantification is most difficult. For the most precise estimates tend also to be the most exaggerated, and more sober experts are reluctant to be precise (e.g. Rosefielde [7950] and accompanying discussion).

In summary, what were the defining features of Soviet primary accumulation after 1928? First, in labour-adjusted roubles agriculture financed a significant but declining proportion of public sector accumulation through unequal exchange. Second, the price "scissors" or terms of trade between industry and agriculture proved resistant to administrative controls and failed to move in a way which would pay for the increase in industrial investment, although they were successfully manipulated to benefit nationalised enterprise at the expense of collective farming within public sector agriculture. Third, trends in the exchange of commodities and terms of trade were incidental to establishment of the decisive condition for Soviet primary accumulation the administrative mobilisation of resources - products and labour - into public sector capital construction of large-scale industrial projects, which was carried out regardless of the consequences for market equilibrium or incentives for small producers. Fourth, the administrative mobilisation of products on this scale would have necessitated changes in agricultural organisation whatever happened, and farm collectivisation was itself a major act of primary accumulation; however, contrary to received opinion, the collectivisation process did not additionally give rise to the expanded flow of products to be mobilised. Fifth, the main constituents of Soviet primary accumulation were the collectivisation of peasant farming and 
its subordination to state enterprise within public sector agriculture, the elimination of private sector small-scale rural industries, the rationing of industrial investment resources exclusively to the public sector and their denial to private enterprise, and the associated movement of millions of workers out of the household and private sector to employment in public sector capital construction at a reduced real wage. From this point of view, the real process of Soviet primary accumulation had more in common with the mobilisation of labour envisaged by Bukharin in 1920, than with the products transfer urged by Preobrazhensky in 1924-26. Sixth, the viability of public sector expansion on this basis was underpinned by the transformation of public sector managerial relations of production and of the economic system as a whole on hierarchical, authoritarian lines.

\section{Lessons}

The experience of Soviet primary accumulation contains several lessons of significance for other developing countries engaged in a transition to socialism. First, primary socialist accumulation goes far beyond the issues of industry versus agriculture, worker versus peasant or town versus village. Soviet primary accumulation brought about radical change within industry and within agriculture, not just in the relations between them; it drastically altered the lives of both workers and peasants, and of both town and country. Even the issue of public versus private enterprise does not sum it up because the nature of the public sector was also profoundly transformed. Thus, even if primary socialist accumulation sometimes appears to narrow itself down to comparatively technical issues such as the pricing of industrial and agricultural commodities, decisions taken on such a narrow basis may turn out to have implications reaching far beyond what was anticipated.

Second, primary socialist accumulation is not a deterministic concept. There is no one course which all developing countries must follow. Within Soviet experience the concept of primary socialist accumulation acquired several different meanings. However, primary socialist accumulation from below, relying on a mixture of worker and community initiatives, co-operative forms and economic methods, appeared less attractive to those in charge of the Soviet political system than primary socialist accumulation enforced from above through administrative mobilisation of resources and the centralisation of authority.

Third, the Soviet pattern of primary socialist accumulation proved viable and had a number of beneficial results. Bukharin and others who had argued that the Soviet state could not launch a confrontation with a hundred million peasants and dispense with their goodwill were proved wrong by Stalin and his colleagues. In the short term this primary accumulation pattern was associated with a sharp deterioration in the quality of life for most Soviet citizens. In the long term, however, an economic system was built which gave rise to full employment, rising living standards and a high degree of economic security for nearly everyone, at least in peacetime conditions. What is more, a Soviet military-economic counterweight to Western imperial pretensions was 
established, without which many of the options for non-capitalist development open to developing countries today would be out of the question.

Fourth, Soviet primary socialist accumulation had many unintended results. Among these were the economic losses resulting from the uncontrolled style of resource mobilisation (including the speed and methods of farm collectivisation), the associated costs of underestimating inertia and reluctance or resistance down below in the face of higher-level directives and decrees, the multiplication and overburdening of centralised administrative controls on economic life, the hyperactivity of the state security organs and proliferation of purges, the spread of forced labour and widespread alienation of working people (especially peasants) from socialist goals. At each stage governmental coercion, first embraced as a temporary expedient or necessary evil, became permanently institutionalised and hailed as a proper characteristic of socialist construction.

Fifth, these features of Soviet primary socialist accumulation meant that the process proved extremely difficult to complete. Even today some aspects of the primary phase persist. The private sector continues to play an irreducible role in Soviet agriculture and trade. Within the public sector an informal economy based on the use of public assets for private gain persists and cannot be eliminated in spite of decrees and directives. Rapid industrialisation has been successfully carried out, yet many elements of the pre-socialist, preindustrial economy have been carried over into the Soviet workplace and urban community - labour indiscipline and migrancy, concealed unemployment, archaic controls on information, culture and popular decision-making. Thus the means originally chosen for building a socialist society turn out to have incorporated unexpected limits on the attainment of the original goal.

Sixth, although the Soviet pattern of primary socialist accumulation was not economically predetermined but resulted from political choice, this choice has proved extremely difficult to revise after the event. Right from the start important sections of Soviet society and public opinion, including influential groups at the heart of the Stalinist political system, were ready to have second thoughts and urge a shift to a less coercive path of primary accumulation with more scope for socialist construction and economic development from below. From time to time they were able to secure significant constraints on the actions of Soviet officialdom and, after the death of Stalin these constraints became permanent. But the basic institutions and mechanisms of rule already laid down had meanwhile become strongly entrenched and today remain powerfully resistant to any more fundamental reform.

\section{References}

Barsov, A. A., 1969, Balans stoimostnykh obmenov mezhdu gorodom i derevnei, Moscow: Nauka.

Barsov, A. A., 1974, "NEP i vyravnivanie ekonomicheskikh otnoshenii mezhdu gorodom i derevnei," in Novaya ekonomicheskaya politika: voprosy teorii i istorii, Moscow: Nauka. 
Brus, Wlodzimierz, 1975, Socialist Ownership and Political Systems, London and Boston: Routledge \& Kegan Paul.

Bukharin, N. L, 1967, Put' k sotsializmu v Rossii. Izbrannye proizvedeniya N. I. Bukharina (ed. Sidney Heitman), New York: Omicron.

Carr, E.H., and R.W. Davies, 1974, Foundations of a Planned Economy 1926-1929, Vol. 1, Harmondsworth: Pelican.

Crisp, Olga, 1976, Studies in the Russian Economy before 1914, London and Basingstoke: Macmillan.

Cohen, Stephen F., 1975, Bukharin and the Bolshevik Revolution: A Political Biography 1888-1938, New York: Vintage.

Danilov, V.P., 1977, Sovetskaya dokolkhoznaya derevnya: naselenie, zemlepol'zovanie, khozyaistvo, Moscow: Nauka.

Davies, R.W., 1977, "The Emergence of the Soviet Economic System 1927-1934," Soviet Industrialisation Project Series No. 9, Centre for Russian and East European Studies, University of Birmingham.

Davies, R. W., 1980, The Socialist Offensive: The Collectivisation of Soviet Agriculture 1929-1930, London and Basingstoke: MacMillan.

Davies, R. W., and S.G. Wheatcroft, 1983, "Soviet National Income Accounts (Balances) for 1928-1930; A Rare Historical Source," Paper presented to the Soviet Industrialisation Project Seminar, Centre for Russian and East European Studies, University of Birmingham. To be published in R. W. Davies and S.G. Wheatcroft, eds.. Materials for the Balance of the Soviet National Economy 1928-1930, Cambridge: Cambridge University Press (forthcoming).

Ellman, Michael, 1975, "Did the Agricultural Surplus Provide the Resources for the Increase in Investment in the USSR during the First Five Year Plan?” Economic Journal, Vol.85, December.

Ellman, Michael, 1978, "On a Mistake of Preobrazhensky and Stalin," Journal of Development Studies, Vol.14, No. 3.

Erlich, Alexander, 1950, "Preobrazhenski and the Economics of Soviet Industrialization," Quarterly Journal of Economics, Vol. LXIV, No. 1.

Filtzer, Donald, 1978, "Preobrazhensky and the Problem of the Soviet Transition," Critique, No. 9.

Gregory, Paul R., 1972, "Economic Growth and Structural Change in Tsarist Russia: A Case of Modern Economic Growth?” Soviet Studies, Vol. XXIII, No.3.

Gregory, Paul R., 1982, Russian National Income 1885-1913, Cambridge: Cambridge University Press.

Harrison, Mark, 1981-82, "Soviet Primary Accumulation Processes: Some Unresolved Problems," Science \& Society, Vol.XLV, No. 4.

Harrison, Mark, 1984, "Why Was NEP Abandoned?" in Robert C. Stuart (ed.). The Soviet Rural Economy, Totowa, NJ: Rowman \& Allanheld.

Kornai, Janos, 1980, The Economics of Shortage, Vol. A, Amsterdam, New York and Oxford: North Holland.

Lewin, Moshe, 1968, Russian Peasants and Soviet Power: A Study of Collectivisation, London: Allen \& Unwin.

Millar, James R., 1970, "Soviet Rapid Development and the Agricultural Surplus Hypothesis,” Soviet Studies, Vol. XXII, No. 1. 
Millar, James R., 1974, "Mass Collectivization and the Contribution of Soviet Agriculture to the First Five-Year Plan: A Review Article," Slavic Review, Vol.33, No.4.

Millar, James R., 1976, "What's Wrong with the 'Standard Story', Problems of Communism, Vol.XXV, No.4.

Millar, James R., 1978, "A Note on Primitive Accumulation in Marx and Preobrazhensky," Soviet Studies, Vol. XXX, No. 3.

Millar, James R., 1984, "Views on the Economics of Soviet Collectivization of Agriculture: The State of the Revisionist Debate," in Robert C. Stuart (ed.). The Soviet Rural Economy, Totowa, NJ: Rowman \& Allanheld.

Morrison, David, 1982, “A Critical Examination of A. A. Barsov's Empirical Work on the Balance of Value Exchange between the Town and Country," Soviet Studies, Vol. XXXIV, No.4.

Nove, Alec, 1976, "The 'Logic' and Cost of Collectivization," Problems of Communism, Vol. XXV, No. 4.

Nove, Alee, 1982, An Economic History of the USSR, 3rd revised edn., Harmondsworth: Pelican.

Preobrazhensky, E., 1965, The New Economics, Oxford: Oxford University Press.

Rosefielde, Steven, 1980, "The First 'Great Leap Forward' Reconsidered: Lessons of Solzhenitsyn's Gulag Archipelago,” Slavic Review, Vol. 39, No. 4.

Stalin, Joseph, 1940, Leninism, London: Lawrence \& Wishart.

Szamuely, Laszlo, 1974, First Models of the Socialist Economic Systems: Principles and Theories, Budapest: Akademiai Kiado.

Vyas, Arvind, 1978, Consumption in a Socialist Economy: The Soviet Industrialisation Experience. 1929-37, New Delhi: People's Publishing House.

Vyas, Arvind, 1979, "Primary accumulation in the USSR revisited," Cambridge Journal of Economics, Vol.3, No.2.

Vyas, Arvind, 1985, "The Contribution of the Soviet Working Class to Industrialisation (1929-1937) and the Question of Historical Alternatives," in R. W. Davies (ed.), Soviet Investment for Planned Industrialisation, 1929-1937: Policy and Practice, Oakland, CA: Berkeley Slavic Specialties (forthcoming).

Wheatcroft, S.G., 1984, "A Reevaluation of Soviet Agricultural Production in the 1920 s and 1930s," in Robert C. Stuart (ed.). The Soviet Rural Economy, Totowa, NJ: Rowman \& Allanheld.

Wheatcroft, S.G., Davies, R. W. and J.M. Cooper, 1982, "Soviet Industrialisation Reconsidered: Some Preliminary Conclusions about Economic Developments between 1926 and 1941," paper presented to the SSRC Conference on Soviet Economic Development in the 1930s (Third Conference of the International Work-Group on Soviet Interwar Economic History), University of Birmingham. To be published in the Economic History Review (forthcoming).

Zaleski, Eugene, 1911, Planning for Economic Growth in the Soviet Union 1918-1932, Chapel Hill, NC: University of North Carolina Press. 